\title{
Security options for Eastern Europe
}

$\mathrm{n}$ spite of the attempts of the West to create an area free form dividing lines Europe becomes more and more fragmented due to the ongoing geopolitical rivalry, struggle for leadership and lack of established and commonly recognized rules of the game. The EU, the US and Russia rely on different values, apply different norms and interpret existing international law, bi- and multilateral instruments in different ways. Russia raises its assertiveness as an instrument to enhance its positions on the world arena and expand room for maneuvering. Expanding its sphere of influence is perceived in Russian strategic culture as a security ring from time to time jeopardized by the opponent West. The concept of Russia as a "besieged fortress"1 is not wallowed in the mists of the time but still explains Russian strategic behavior, foreign and security politics. The EU strives for the security zone on its eastern borders and the best option to do that is deeper integration of neighbors and convergence of national politics with those of the EU. The line between these visions, strategies and ambitions becomes a vulnerable and fragile zone.

When we look at the map of Europe, we can distinguish the security and economic systems shaped by the EU and NATO as well as one in the East shaped by Russia (Eurasian Economic Union with its Customs Union (EEU), Collective Security Treaty organization (CSTO)) and a marginal zone embracing Ukraine, Georgia and Moldova. And these three states constitute a grey zone in Eastern Europe now.

Why do we attribute these states to the grey zone in Eastern Europe? Here in this article the author relies on the broad concept of Eastern Europe embracing the states to the east from Germany and Austria, including the Balkans, Baltic states and South Caucasus. The key dividing line for distinguishing the grey zone is membership in integration structures like the EU or EEU or security structures like NATO or CSTO. In mid-term perspective, after the EU and NATO finish absorbing the Balkans, Ukraine,

1 O. Lytvynenko, The Talons of the Double-Headed Eagle: A Sketch of Russian Strategic Culture, Royal College of Defence Studies, London 2013, p. 34. 
Georgia and Moldova will remain the only grey zone in Europe. As for Belarus and Armenia, both are members of the EEU as well as CSTO. Azerbaijan, though united together with the EU-inclined Georgia and Armenia in the Eastern Partnership Program, has never declared its intention to join either EU or NATO. It's foreign policy priorities are very diverse and prioritize relations with the US, Iran, Persian Gulf states as well as Russia.

Currently when the Russian-Ukrainian conflict is evolving NATO strengthens conventional deterrence within its Eastern Flank reacting to the Russian military activity the grey zone appears to be more and more isolated and lacking security mechanisms. The strategic rebalancing is aggravated by posturing the three states at the crossroad of the Russian-crafted anti-access/area-denial (A2AD) exclusion zones (especially regarding militarization of Crimea) and on the other hand of NATO deployed military forces in Poland, Baltic states, Bulgaria and Romania. These processes outline the margins of the grey zone in Eastern Europe more and more clear and eloquent.

So, in this article the author concentrates on the security options for the grey zone in Eastern Europe that is of great importance not only for the states their selves, but for the whole Europe as well.

\section{Specific features of the grey zone}

What is the essence of the grey zone and what particular common features do the states share? States are attributed to the grey zone when they stay outside of any regional security mechanisms or institutions and do not experience any credible security guarantees; do not have efficient tools of security provision and resilience building; face permanent potential or real challenges; stay between two opposing security systems actors of which exert significant impact on the marginal states; relations with the neighboring powers are burdened with the asymmetry of power interaction; states have weak political and economic systems that is used by external actors as a leverage of pressure; states lack strictly defined foreign policy orientation and have hardly predictable perspectives.

In this sense they jeopardize regional security and risk to be or to be transformed into an object of foreign and security policy of a stronger power together with possible loosing of statehood.

Grey zones as well as marginal states were widely discussed in geopolitical surveys like "statterbelts" by Sol Cohen, Joseph Partsch Mitteleuropa, Halford Mackinder's and Nicholas Spykman's ideas ${ }^{2}$ of marginal zones; in security regionalism of Barry Buzan and Ole Waever who distinguished states-insulators and states-overlays ${ }^{3}$. Ukraine, Georgia and Moldova can also be called "countries in-between", "stuck in the middle" or "shared

2 S. Cohen, Geography and Politics in a World Divided. - London, 1963, p. 18; K. Dodds, D. Atkinson, Geopolitical Traditions. A century of geopolitical thought, London 2000, p. 27-51.

3 B. Buzan, O.Waever, Regions and Powers: The Structure of International Security, New York 2003, p. 28. 
neighbourhood" - a term commonly used since the EU Neighbourhood Policy emerged indicating an area between the EU and Russia, in fact area of geopolitical rivalry and contention. Common denominator for these states is shared challenges and threats of both internal and external nature. For Ukraine, Georgia and Moldova they are:

- Security deficit and protracted conflicts;

- Parts of territories occupied by Russian troops with quasi-state entities under Moscow's control;

- Ongoing military provocations or even hostilities in case of Ukraine (for example, Russian provocations in Georgia in 2015 when Russia moved the internal demarcation line between South Ossetia and the main territory of Georgia a few hundred meters further into Georgia);

- Permanent Russias attempts to subordinate internal and external policy to Moscow, to limit the sovereignty, to impose Russia-lead integration projects;

- Strong Russian influence via corrupted politicians, business, criminals, media, Russian Orthodox Church;

- Economic pressure via open and hidden Russia-imposed restrictions on trade with the CIS countries, including transit restrictions;

- Lack of reliable security guarantees and of allies, limited Western support. The very idea of security guarantees was highly discredited by the Budapest Memorandum on Security Assurances ${ }^{4}$ of 1994 which granted Ukraine security assurances of great powers for its nuclear disarmament;

- Internal threats: inconsistent reforms, political turbulence, weak economies.

The majority of these threats shaped the so called "negative identity" of these three states meaning that all of them perceive as a principle common threat first and foremost Russian revisionism. Staying under the pressure of Russian policy directed at making the states of the grey zone "weak states" wallowed in corruption, dependence, authoritarian regime and deprived of the strategic goals - thus establishing the control over their domestic and foreign policy.

All the three states have Russian troops on their territory, face economic sanctions from Moscow, are subject to Russian media influence that broadcast Kremlin-invented reality (it is less in Georgia with a lesser percent of Russia-speaking population, but it is very tangible in Ukraine). In Moldova, the nearly $50 \%$ of the population receives most of its news from the Russian media ${ }^{5}$. Operational group of Russian forces in Transnistria being the continuation of the USSR $14^{\text {th }}$ army are not the phenomenon of independence period. Russian troops still stay at the territory of recognized by it as independent Abkhazia and South Ossetia though obliged to be withdrawn by Oct. 1,

4 Верховна Рада України http://zakon5.rada.gov.ua/laws/show/998_158 “Меморандум про гарантії безпеки у зв’язку з приєднанням України до Договору про нерозповсюдження ядерної зброї, last entrance: 2.12.2017

5 The German Council on Foreign Relations (DGAP), https://dgap.org/sites/default/files/article_ downloads/ostpolitik_workingpaper_herbst.pdf J. Herbst "Forsaken Territories? The Emergence of Europe's Grey Zone and Western Policy”, last entrance: 2.12.2017. 
2008. Militarization by Russia of the annexed Crimea and undeclared and unrecognized presence of Russian forces at the territory of quazi-states Luhansk and Donetsk Peoples' Republics is the most recent example of Russian assertiveness in the grey zone.

Grey zone pose challenges by its only existence for both - the states embraced in it and the external actors. In case of Ukraine, Georgia and Moldova such challenges include risks of loosing sovereignty, independence and statehood; staying outside regional security mechanisms/institutions; lacking efficient tools of security provision and resilience building; unstable political, economic and security situation; unfavorable environment for reforms; lack of foreign investments.

Preserving the grey zone in Eastern Europe pose a set of challenges for the EU and NATO. Grey zones will stay a field of permanent tensions and contention between the West and Russia with constant instability on the EU/NATO Eastern borders and military trainings Zapad-2017 serves as a bright illustration. Permanent threat of largescale military conflict with respective negative consequences for the whole region will not contribute to mutual trust and transparency. Such instability invites Russia to create new grey zones of destabilization as an instrument of Moscow's foreign policy (like it was in Montenegro in 2016 or Serbia). Russia will proceed with skillful exploitation of crafted by it phenomenon of instability to promote its own version of the world order and security order. The Draft on the European Security Treaty ${ }^{6}$ of 2009 proves this thesis.

\section{Security options for the grey zone states}

United by common threats and challenges the grey zones states can search for joint options to escape from the marginal status. Regarding strategic environment and aiming to overcome the existing threats and challenges the grey zone states may navigate within the following options:

1. Maintaining current status quo.

2. Neutrality with strong guarantees of major powers.

3. Relying on strengthened/modified international security mechanisms (OSCE, $\mathrm{UN}$ ) or establishing new ones.

4. Sub-regional cooperation and alliances (Bi / Multi).

5. Bilateral security agreements with the US.

6. Joining one of the existing security systems.

2.1. Current status quo can be considered as the worst but most possible option especially for the short-term perspective. This would mean an ongoing instability with risks of aggravation favorable only for Russia although not meeting Moscow's ultimate goals. The principle drawback is preserving the asymmetric interdependence with Russia as

6 Official Internet Resources of the President of Russia http://en.kremlin.ru/events/president/ news/6152 "The draft of the European Security Treaty", November 29, 2009, last entrance: 3.12. 2017. 
well as tools of control by the Russian Federation over the states' foreign policy orientation. In this scenario the states will always be the region of high strategic and geopolitical contention.

The only possible advantage of this option is the realization by Ukraine, Georgia and Moldova of the necessity to rely just only on their own forces and build resilience. Ukraine has done the first step - indicating such approach its recent National Security Strategy ${ }^{7}$ version.

\subsection{Neutrality (with strong guarantees of major powers)}

Among the three states of the grey zone Moldova is neutral and it is written in the Constitution while Georgia is not and Ukraine just declared its intention to be a neutral state in the Declaration of the Sovereignty of 1990 but since that time has never fixed this status in the national legislation. Nor this status is supported by any international instrument and guarantees like Austria, Ireland or Switzerland has. Budapest assurances are perceived in Ukraine as absolutely discredited mechanism of securing though it didn't promise any guarantees indeed. Ukraine experienced the non-bloc or nonaligned status from 2010 to 2014. Such status was directed at reducing Russian pressure on Ukraine accommodating its anxiety regarding Ukraine's NATO drift. But this did not exempt her from Russian primarily economic and energy pressure coupled with military one in 2014.

The proponents of this idea ${ }^{8}$ in the West stress neutral status would help the West to feel more comfortable by accommodating Moscow in its neighborhood at least in order to provide its cooperation on issues such as defeating the Islamic State, Syrian issue or Iranian denuclearization talks. The proponents of "finlandization" version" (that means EU membership without NATO) believe Russia will accept these states' drift towards the EU. But as the prospect of Ukrainian Association agreement showed as well as Moldovan approaching the EU and the last presidential elections, it seems to be an illusion. Russia always considered neutral/non-allied status of Ukraine and Moldova as a temporary compromise and just a stage on the way of incorporating them to the Moscow-initiated integration structures.

7 Верховна Рада України http://zakon3.rada.gov.ua/laws/show/287/2015 “Про рішення Ради національної безпеки і оборони України від 6 травня 2015 року “Про Стратегію національної безпеки України", 26 May, 2015, last entrance: 15.09.2017.

8 The German Council on Foreign Relations (DGAP), https://dgap.org/sites/default/files/article_ downloads/ostpolitik_workingpaper_herbst.pdf J.Herbst "Forsaken Territories? The Emergence of Europe's Grey Zone and Western Policy", last entrance: 02.12.2017.

9 The Washington Post, https://www.washingtonpost.com/opinions/henry-kissinger-to-settle-theukraine-crisis-start-at-the-end/2014/03/05/46dad868-a496-11e3-8466-d34c451760b9_story.html?utm_term=.55f27ab33ece "Henry Kissinger: To settle the Ukraine crisis, start at the end", March 5, 2014, last entrance: 30.09.2017; Bloomberg, https://www.bloomberg.com/news/articles/2014-04-11/ brzezinski-sees-finlandization-of-ukraine-as-deal-maker "Brzezinski Sees Finlandization of Ukraine as Deal Maker”, April12, 2014, last entrance: 30.09.2017. 
Swiss neutrality as well as Austrian is guaranteed by the great states. Any of them will hardly provide such guarantees for Ukraine or Georgia regarding Russian interest and engagement in their domestic development as well as foreign and security politics.

As recent trends show neutral European states like Sweden and Finland revise their status considering it as irrelevant in current environment and such that does not provide their security. Discussions on joining NATO are more and more spread in domestic political discourses. At last, this option will retain the grey zone that is favorable neither for the three states nor for Europe.

2.3. Strengthening of OSCE and UN or establishing new international security mechanisms: No prospects in the mid-term perspective

The value of the UN and OSCE in dealing with the problems of the grey zone is essential but they lack efficient tools of influence to provide peace and stability in the three states. The UN has a toolbox of peacemaking instruments that could be applied but for all the UN missions the consent of the states participants is needed except of peace-enforcement mission that is irrelevant first of all because Russia will never recognize its role in destabilizing the states. This is the principle reason why no decision can be provided via the UN Security Council where Russia sits as a permanent member. The OSCE has its monitoring missions in the conflict zones. They fulfill important work but cannot bring resolution to the conflicts. The need in reforming both international organizations is discussed during a long time and obviously will not be provided in the near-term future.

So, as the practice shows, the first three options do not seem to be efficient and relevant. Let us analyze another three.

\subsection{Sub-regional cooperation and alliances}

Among the reasons driving two or more states to security cooperation can be mutually beneficial results of cooperation that will bring a new quality and conquering a common threat or challenge. Ukrainian-Polish Military Cooperation is a good illustration of bilateral cooperation directed at enhancement of mutual security. Defense Concept of the Republic of Poland 2017 as well as the National Security Strategy of Ukraine 2015 consider Russia as a principle threat - for the first time. Among the principle illustrations of such cooperation are:

- Agreement between Ukraine, Poland and Lithuania on the establishment of a joint military unit (with the headquarter in Lublin (opened in January 2016)). The Brigade includes over 4,000 soldiers with the three years term of office with the possibility of further extension. Executed and planned participation in the "Saber Guardian" command-and-control exercise in Bulgaria, the "Rapid Trident" exercise (by the US Army in Ukraine), exercises "Maple Arch 17" at the training ground in Poland. 
- General Agreement between the Cabinet of Ministers of Ukraine and the Government of the Republic of Poland on Cooperation in Defense Sphere (signed in Warsaw on December 2, 2016);

- Agreement on Strategic Cooperation between Polish armaments company "Lubawa S.A." and UKROBORONPROM (2014) (modern helmets and bulletproof vests were supplied);

- Polish private armaments company "WB Electronics", a producer of UAV (drones) and observation systems, capable of operating day and night, entered the Ukrainian market and significantly improved the equipment of unmanned systems in Ukrainian units;

- projects discussed on construction of a Polish-Ukrainian multi-role helicopter as well as modernizing of the owned by the Polish army ones with the Ukrainian Motor Sich engines. Ukrainian experience in missile technology, design of radar and early warning systems, may be of interest for Poland ${ }^{10}$.

And regardless the fact that Ukraine has tense relations with its neighbors, they realize the benefits of such bilateral cooperation as well as subregional one in the face of common threat. According to the Polish Public Opinion Research Center's report ${ }^{11}$, in February 2015 75\% of the Poles considered Russian aggression as a threat for their country's security. Here they stay very close in their security concerns to Ukraine and Baltic states and more distant from those of the $\mathrm{V} 4$ who are more loyal towards Russia.

In this context the Intermarium concept originally Polish idea of geopolitical nature comes to be relevant with its security component. The Combined military capacity of Poland, Ukraine and Lithuania could be the most powerful in Europe, including 380 thousand of military personnel, over 2,000 of tanks, over 800 pieces of multiple-launch rocket systems and over 600 military aircrafts.

GUAM as a previous experience of subregional cooperation between Ukraine, Georgia, Moldova together with Azerbaijan in economic, energy and security domain failed because of the lack of political will, external support, changing political views in Moldova together with lack of financial resources for implementation of the projects declared. Visegrad $4+1$ format is another idea for subregional cooperation in security domain where Ukraine is interested to be included. But due to the tense in relations with neighbors is postponed. One more example of Ukraine's participation in multilateral format is the EU battle groups like "HELBROC" and Visegrad EU battlegroup.

10 The Warsaw Institute Review https://warsawinstitute.org/defense-cooperation-between-poland-and-ukraine-present-state-and-prospects/ A.Romanowska, "Defense Cooperation between Poland and Ukraine: Present State and Prospects", June 2017, last entrance: 6.12.2017.

11 Pew Research Center http://www.pewglobal.org/2015/06/10/1-nato-public-opinion-wary-of-russialeary-of-action-on-ukraine/ "NATO Public Opinion: Wary of Russia, Leery of Action on Ukraine", June, 2015, last entrance: 6.12.2017. 


\subsection{Bilateral security agreements with the US}

The idea of reliance on powerful allies like the US is very popular in Ukraine since Russian aggression. Ukraine looked for the status of the US Major Non-NATO ally (MNNA) in 2014 when the Ukraine Freedom Support Act ${ }^{12}$ was approved by the US Congress. But the Obama administration stressed the importance of the distinctive partnership with NATO as a prerogative and denied the MNNA status. The second appeal is made to the Trump administration but yet without success.

What does the MNNA status mean in the US foreign policy practice? According to the Section 2350a(f)(2) of Title 10, United States Code and Section 517 of the Foreign Assistance Act of 1961 (with the amendments) the status of a strategic ally envisage granting significant military and financial aid to a strategically "close ally" (like Israel, Japan, South Korea etc.); intelligence sharing; training on a bilateral or multilateral basis under reciprocal financial arrangements; commercial leasing of certain defense articles; loans of materials, supplies and equipment for cooperative R\&D projects and testing and evaluation; permits firms of the country to bid on certain USG contracts for maintenance, repair or overhaul of DOD equipment outside the Continental US; joint counterterrorism research \& development projects; to have U.S.-owned War Reserve Stockpiles on its territory outside of U.S. military installations etc. ${ }^{13}$

For Ukraine the MNNA status would have first and foremost a symbolic essence like a tool and leverage of Russia deterrence. But still Ukraine should keep in mind the words of the Canadian Foreign Minister Chrystia Freeland, a Ukrainian by origin, who gave a clear answer, why one should invest in his own defense rather than rely on an ally: "Some think, some even say, we should therefore free ride on U.S. military power. Why invest billions to maintain a capable, professional, well-funded and well-equipped Canadian military? The answer is obvious: To rely solely on the U.S. security umbrella would make us a client state. And although we have an incredibly good relationship with our American friends and neighbors, such a dependence would not be in Canada's interest. That is why doing our fair share is clearly necessary ${ }^{14}$ ".

Another form of bilateral rapprochement with the US in the security domain is the conclusion of the defense cooperation treaties which would also have a symbolic meaning in case of the grey zone states. But the main obstacle here is lack of trust between the partners as well as circumspective approach towards risks of aggravating relations with Russia.

12 Congress.Gov https://www.congress.gov/bill/113th-congress/senate-bill/2828/text S.2828 - "Ukraine Freedom Support Act" of 2014, last entrance: 30.11.2017.

13 GlobalSecurity.Org, https://www.globalsecurity.org/military/agency/dod/mnna.htm "Major NonNATO Ally (MNNA)", last entrance: 7.12.2017.

14 Government of Canada, https://www.canada.ca/en/global-affairs/news/2017/06/address_by_minis terfreelandoncanadasforeignpolicypriorities.html "Address by Minister Freeland on Canada's foreign policy priorities", June 6, 2017, last entrance: 1.12.2017. 


\subsection{Joining one of the existing security systems}

Disappearance of grey zone that is favorable first of all for the states included in it first and foremost because this would mean reducing Russian pressure and shift from the object of geopolitical rivalry to subject of regional interaction and contributor of regional security.

While Georgia and Ukraine has NATO membership aspirations and move gradually to this direction, Moldova is on its way of defining foreign policy and security strategy. Georgia is listed among potential candidates for NATO membership, it was granted special Enhanced Opportunities Partnership pattern of relations. The polls constantly show rising popularity of EU and NATO accession in both states. In Ukraine according to polls of $2017^{15} 69 \%$ favor the accession to the EU with $31 \%$ against, and with $56 \%$ for joining NATO with $44 \%$ against. In Georgia according to the polls of $2017^{16}$, support for the EU integration is $80 \%$ and $68 \%$ for NATO.

Regarding Moldova the situation is very disputable. Here the sympathies to the Eurasian Economic Union are dominant: 52\% of citizens would vote for Moldova's integration with the Eurasian Economic Union (30\% against) and with $42 \%$ with the European Union ( $36 \%$ against $)^{17}$. The issue of NATO joining is not even included in the poll as Moldova does not discuss such an option being a neutral state.

One of the main drawbacks of this version is time. Membership perspective is a mid- or long-term perspective. And the states need security now.

A huge challenge now is adherence by many influential and experienced politicians and experts to the idea of sharing by the three states a two-dimensional approach in foreign policy due to their geopolitical position and historic experience. Ukrainian example of balancing between the European and Eurasian (Russia-led) dimensions in its foreign policy during more than 20 years led to highly dangerous implications jeopardizing not only national but regional security.

\section{Exploitation of existing toolbox}

While the prospect of EU/NATO membership is rather remote the existing framework for cooperation between EU/NATO and the three states provides a broad security toolbox. The whole logic of bilateral relations is driven today by building resilience aimed at crafting security and defense capabilities of the states to withstand threats and aggression by their own forces.

15 Kyiv International Institute of Sociology, http://www.kiis.com.ua/?lang=eng\&cat=reports\&id=71 3\&page $=1$ "Geopolitical orientations and attitude of the residents of Ukraine to the independence of Ukraine”, 20 VIII 2017, last entrance: 1.10.2017.

16 National Democratic Institute and CRRC Georgia - April 2017, https://www.ndi.org/publications/ ndi-poll-georgians-increasingly-support-eu-and-euro-atlantic-aspirations-view-russia "NDI poll: Georgians increasingly support EU and Euro-Atlantic aspirations; view Russia as a threat", May 2017, last entrance: 1.10.2017.

17 News Agency Infotag, http://www.infotag.md/populis-en/246302/ "52\% Moldovans stand for integration with EAES and 42\% with EU - Opinion Poll", May 25, 2017, last entrance: 1.10.2017. 
Resilience is a comprehensive concept developed within the Euro-Atlantic community to respond to a new array of hybrid threats by combining civilian, economic, commercial and military capabilities. During the NATO Warsaw Summit, resilience was adopted as the guiding principle being defined as "society's ability to resist and recover easily and quickly from internal or external shocks, combining civilian, economic, commercial and military factors ${ }^{18}$." NATO principal approach today is: projecting stability that is in the words of the Secretary General Jens Stoltenberg "using our (NATO) forces to train others to fight"19.

Deepening cooperation with the EU. All the three states enjoy the benefits of the Association Agreement and Deep and Comprehensive Free Trade Area (DCFTA) since 2013 for Moldova and 2014 for Ukraine and Georgia. Moldova was the first to establish a visa free travel regime in 2014 followed by Ukraine and Georgia in 2017. All the three are embraced by the Eastern Partnership Program focusing on good governance, reforming public energy sector, public administration and justice sector reforms, agriculture and rural development, police reform, support for SMEs, academic mobility, enhancement of civil society, energy partnership.

The EU fulfils Border Assistance Mission to Moldova and Ukraine (launched in 2005) and Advisory Mission to Ukraine for Civilian Security Sector Reform (since 2014 EUAM), established the post of the EU Special Representative for the South Caucasus and the crisis in Georgia as well as the EU Monitoring Mission (EUMM).

The EU engagement in Russian-Ukraine conflict is demonstrated by the sanctions imposed on Russia, humanitarian aid delivered to the eastern territories of Ukraine, internally displaced persons, financing of early recovery and peacebuilding operations.

\section{Deepening cooperation with NATO}

After Ukraine and Georgia failed to obtain the Membership Action Plan at NATO Bucharest summit of 2008 the states stood on the way to achieve NATO standards on a voluntary basis. Ukraine being guided by the distinctive partnership status in relations with NATO articulated its membership ambitions in the recent National Security Strategy and Military Doctrine of Ukraine. The distinctive partnership equips Ukraine with consultation mechanisms it exploits during the conflict. Among the tools NATO proposes for the resilience building of Ukrainian security and defense sector special place possess Comprehensive Assistance Package for Ukraine aimed at strategic advice and assistance including critical infrastructure protection, security and defense sector reform, education and training, de-mining and countering improvised explosive

18 North Atlantic Treaty Organization https://www.nato.int/cps/ic/natohq/topics_132722.htm "Resilience and Article 3", 22 June, 2016, last entrance: 20.09.2017.

19 North Atlantic Treaty Organization, http://www.nato.int/cps/en/natohq/opinions_129758. htm'Projecting Stability: Charting NATO's Future', Speech by NATO Secretary General Jens Stoltenberg, 6 August, 2016, last entrance: 20.09.2017. 
devices in Donbas, and the operation of outdated weaponry. A complex of Programs and Trust funds, strategic communications efficiency among the public authorities are efficient mechanisms of resilience and capacities building. In 2017 NATO Mission to Ukraine was officially launched as a demonstration of deepening relations.

NATO sees Georgia as its most plausible member the illustration of what can be granting Georgia the Enhanced Opportunities partnership together with Sweden, Finland, Australia and Jordan. Georgia develops Defense and Related Security Capacity Building. Joint Training and Evaluation Centre to drill Georgian military units and allies was launched. Substantial NATO-Georgia Package (SNGP) includes support to thirteen areas of defense and security-related sectors as well as advisory support.

Moldova having less sentiments to NATO exploits Individual Partnership Action Plans, Defense and Related Security Capacity Building aimed at transformation of Moldova's armed forces, and deeper engagement in the areas of cyber security, defense education, building integrity, ammunition storage and safety, security sector reform, improving defense capabilities.

All the three states use the toolbox of the Partnership for Peace program that hosts a lot of bilateral programs like, for example, Professional Development Program (Ukraine and Georgia) that has a special significance for training current and future generation of military servants.

\section{Recommendations}

1. Ukraine, Georgia and Moldova should consolidate cooperative efforts between them as well as efforts with external partners aimed at preventing conservation of the grey zone. Special attention should be paid to common diplomatic and information efforts abroad, counter-propaganda and cyber security issues.

2. The states should consistently exploit the existing mechanisms of cooperation between them and the EU as well as NATO. The variety of tools provided by these actors to the states of the grey zone in case of their full and efficient exploitation can give rich benefits for the states' security.

3. With regard to the long-term perspective of accession to the EU and NATO Ukraine, Georgia and Moldova should maintain and develop their resilience and reduce their dependence on Russia in such key spheres as: energy, banking sector, media. While Georgia and Ukraine reduced their dependence on Russian energy resources to a minimum (Ukraine doesn 't but Russian gas since 2015 but imports coal for the thermal stations from Russia, and just $10 \%$ of Georgian gas import comes from Russia) 80 percent of Moldovan electricity and all natural gas come from a single source - Russia. Besides, a huge debt attributed to Moldova for the Transnistria gas consuming from Russia that enhance Moldovan dependence on the latter.

4. Exploitation of all possible options of bilateral and multilateral cooperation should be applied with a special attention to those which enforce resilience and do not contradict the goals of European and Euroatlantic integration. 


\title{
$\infty$
}

\begin{abstract}
The European continent remains fragmented with Eastern Europe as the most vulnerable region where the grey zone comprising Ukraine, Moldova and Georgia lacks security and challenges regional security. "Countries in-between" were distinguished in a grey zone basing on common internal and external threats; staying outside major functioning security and economic systems shaped by the EU/NATO and EEU/CSTO, actors of which exert a significant impact on the marginal states; burdened by asymmetry of power interaction with neighboring states and entities; weak and unstable political and economic systems.

United by common threats and challenges the grey zones states can search for joint options to escape from the marginal status. Thus, regarding strategic environment and aiming to overcome the existing threats and challenges the grey zone states may navigate within the following options: maintaining current status quo; neutrality with strong guarantees of major powers; relying on strengthened / modified international security mechanisms or establishing new ones; sub-regional cooperation and alliances; bilateral security agreements with the US; joining one of the existing security systems. The author stresses that the most viable and efficient are the last three ones.
\end{abstract}

Keywords: regional security, Eastern Europe, grey zone, countries-in-between, EU, NATO, Russia, the US, Ukraine, Georgia, Moldova

\section{Opcje bezpieczeństwa dla Europy Wschodniej}

Streszczenie: Kontynent europejski pozostaje rozdrobniony, a Europa Wschodnia jest najbardziej narażonym regionem, w którym szara strefa obejmująca Ukrainę, Mołdawię i Gruzję nie jest bezpieczna i stanowi wyzwanie dla bezpieczeństwa regionalnego. „Kraje pośrednie” wyróżniono w szarej strefie na podstawie wspólnych zagrożeń wewnętrznych i zewnętrznych: pozostawanie poza głównym funkcjonującym systemem bezpieczeństwa i systemami gospodarczymi ukształtowanymi przez UE/NATO i EUG/CSTO, których aktorzy wywierają znaczący wpływ na państwa marginalne; obciążenie asymetrią interakcji władzy z sąsiednimi państwami i podmiotami; słabe i niestabilne systemy polityczne i gospodarcze.

Zjednoczeni wspólnym zagrożeniami i wyzwaniami państwa szarej strefy mogą szukać wspólnych opcji, aby uciec od marginalnego statusu. I tak, w odniesieniu do środowiska strategicznego i dążenia do przezwyciężenia istniejących zagrożeń i wyzwań stany szarych stref mogą poruszać się w ramach następujących opcji: utrzymanie obecnego status quo; neutralność z silnymi gwarancjami mocarstw; poleganie na wzmocnionych/zmodyfikowanych mechanizmach bezpieczeństwa międzynarodowego lub ustanawianie nowych; współpraca subregionalna i sojusze; dwustronne umowy bezpieczeństwa z USA; dołączenie do jednego z istniejących systemów bezpieczeństwa. Autor podkreślił, że najbardziej opłacalne i skuteczne są te trzy ostatnie.

Słowa kluczowe: bezpieczeństwo regionalne, Europa Wschodnia, strefa szara, kraje pośredniczące, UE, NATO, Rosja, USA, Ukraina, Gruzja, Mołdawia 


\section{Альтернативы безопасности для Восточной Европы}

Аннотация: Европейский континент по-прежнему фрагментирован и Восточная Европа в нем выступает как наиболее уязвимый регион, где серая зона, в которую входят Украина, Молдова и Грузия, испытывает дефицит безопасности и откуда исходят вызовы региональной безопасности. «Промежуточные страны» были выделены в серую зону на основании общих внутренних и внешних угроз: остаются вне основных функционирующих систем безопасности и экономики, сформированных ЕС/НАТО и ЕЭП/ОДКБ, субъекты которых оказывают значительное влияние на пограничные государства; обремененные асимметрией силового взаимодействия с соседними государствами и объединениями; слабые и нестабильные политические и экономические системы. Объединенные общими угрозами и вызовами, государства серой зоны могут искать совместные варианты выхода из пограничного статуса. Таким образом, учитывая стратегическое пространство и стремление к преодолению существующих угроз и вызовов государства серой зоны могут выбирать из следующих опций: сохранение текущего статус-кво; нейтралитет с мощными гарантиями великих держав; опора на усиленные/измененные механизмы международной безопасности или создание новых; субрегиональное сотрудничество и альянсы; двусторонние соглашения о безопасности с США; присоединение к одной из существующих систем безопасности. Автор подчеркивает, что наиболее эффективными являются последние три.

Ключевые слова: региональная безопасность, Восточная Европа, серая зона, промежуточные государства, ЕС, НАТО, Россия, США, Украина, Грузия, Молдова

\section{Bibliography}

Bloomberg, https://www.bloomberg.com/news/articles/2014-04-11/brzezinski-sees-finlandization-ofukraine-as-deal-maker "Brzezinski Sees Finlandization of Ukraine as Deal Maker", April12, 2014, last entrance: 30.09 .2017 .

Buzan B., Waever O., Regions and Powers: The Structure of International Security. New York 2003, p. 570. Cohen S., Geography and Politics in a World Divided. - London, 1963.

Congress.gov, https://www.congress.gov/bill/113th-congress/senate-bill/2828/text S.2828 - Ukraine Freedom Support Act of 2014, last entrance: 30.11.2017.

Dodds K., Atkinson D., Geopolitical Traditions. A century of geopolitical thought, London 2000, p. 392.

GlobalSecurity.org, https://www.globalsecurity.org/military/agency/dod/mnna.htm "Major Non-NATO Ally (MNNA)", last entrance: 7.12.2017.

Government of Canada, https://www.canada.ca/en/global-affairs/news/2017/06/address_by_ministerfreelandoncanadasforeignpolicypriorities.html "Address by Minister Freeland on Canada's foreign policy priorities", June 6, 2017, last entrance: 1.12.2017.

Kyiv International Institute of Sociology, http://www.kiis.com.ua/?lang=eng\&cat=reports\&id=713\&pa$\mathrm{ge}=1$ "Geopolitical orientations and attitude of the residents of Ukraine to the independence of Ukraine", 20 VIII 2017, last entrance: 1.10.2017.

Lytvynenko 0., The Talons of the Double-Headed Eagle: A Sketch of Russian Strategic Culture, Royal College of Defence Studies, London, 2013, p. 34.

National Democratic Institute and CRRC, https://www.ndi.org/publications/ndi-poll-georgians-increasingly-support-eu-and-euro-atlantic-aspirations-view-russia "NDI poll: Georgians increasin- 
gly support EU and Euro-Atlantic aspirations; view Russia as a threat", May 2017, last entrance: 1.10.2017.

News Agency Infotag, http://www.infotag.md/populis-en/246302/ "52\% Moldovans stand for integration with EAES and 42\% with EU - Opinion Poll", May 25, 2017, last entrance: 1.10.2017.

North Atlantic Treaty Organization, http://www.nato.int/cps/en/natohq/opinions_129758.htm'Projecting Stability: Charting NATO's Future', Speech by NATO Secretary General Jens Stoltenberg, 6 August, 2016, last entrance: 20.09.2017.

North Atlantic Treaty Organization, https://www.nato.int/cps/ic/natohq/topics_132722.htm "Resilience and Article 3", 22 June, 2016, last entrance: 20.09.2017.

Official Internet Resources of the President of Russia, http://en.kremlin.ru/events/president/news/6152 "The draft of the European Security Treaty", November 29, 2009, last entrance: 3.12.2017.

Pew Research Center, http://www.pewglobal.org/2015/06/10/1-nato-public-opinion-wary-of-russialeary-of-action-on-ukraine/ "NATO Public Opinion: Wary of Russia, Leery of Action on Ukraine", June, 2015, last entrance: 6.12.2017.

The German Council on Foreign Relations (DGAP), https://dgap.org/sites/default/files/article_downloads/ostpolitik_workingpaper_herbst.pdf J. Herbst "Forsaken Territories? The Emergence of Europe's Grey Zone and Western Policy", last entrance: 2.12.2017.

The Warsaw Institute Review, https://warsawinstitute.org/defense-cooperation-between-poland-andukraine-present-state-and-prospects/ Romanowska A., "Defense Cooperation between Poland and Ukraine: Present State and Prospects", June 2017, last entrance: 6.12.2017.

The Washington Post, https://www.washingtonpost.com/opinions/henry-kissinger-to-settle-the-ukraine-crisis-start-at-the-end/2014/03/05/46dad868-a496-11e3-8466-d34c451760b9_story.htmI?utm_term=.55f27ab33ece "Henry Kissinger: To settle the Ukraine crisis, start at the end", March 5, 2014, last entrance: 30.09 .2017$.

Верховна Рада України, http://zakon5.rada.gov.ua/laws/show/998_158 «Меморандум про гарантії безпеки у зв'язку з приєднанням України до Договору про нерозповсюдження ядерної зброї», last entrance: 2.12.2017.

Верховна Рада України http://zakon3.rada.gov.ua/laws/show/287/2015 “Про рішення Ради наці ональної безпеки і оборони України від 6 травня 2015 року “Про Стратегію національної безпеки України", 26 May, 2015, last entrance: 15.09.2017. 